\title{
Dialektika Hukum Trading Saham Syariah di Bursa Efek Indonesia
}

\author{
Kharis Fadlullah Hana \\ Institut Agama Islam Negeri Kudus \\ kharis@iainkudus.ac.id
}

\begin{abstract}
This study aims to find out how the legal basis and stock trading transactions that occur in the Islamic capital market in Indonesia. This study uses a field research method that discusses legal issues regarding stock trading based on field studies from various relevant sources. The capital market is a place for corporate activities to seek additional funds to finance its business activities. In Indonesia alone there are two capital markets, namely the regular capital market and the Islamic capital market. The Islamic capital market is a new breakthrough that has been carried out as a solution to the current trend of halal investment. It also becomes very interesting for the community, especially for Muslim communities to invest their capital in the company to get results and can participate in developing the company, but the reality that happens in the market is that many companies that have been listed on the stock exchange are still operating in accordance with sharia principles. The Islamic capital market can simply be interpreted as a capital market that implements sharia principles in economic transaction activities and apart from things that are prohibited such as usury, gambling and speculation.
\end{abstract}

Keywords: Trading law and stock sharia.

\begin{abstract}
Abstrak
Penelitian ini bertujuan untuk mengetahui bagaimana dasar hukum dan transaksi trading saham yang terjadi pada pasar modal syariah di Indonesia. Penelitian ini menggunakan metode field research yang membahas permasalahan hukum mengenai trading saham berdasarkan studi lapangan dari berbagai sumber yang relevan. Pasar modal merupakan tempat kegiatan perusahaan untuk mencari tambahan dana untuk membiayai kegiatan usahanya. Di Indonesia sendiri terdapat dua pasar modal yaitu pasar modal regular dan pasar modal syariah. Pasar modal syariah merupakan suatu trobosan baru yang dilakukan sebagai solusi meningkatknya trend investasi halal saat ini. Hal ini juga menjadi sangat menarik bagi masyarakat terutama bagi masyarakat muslim untuk menanamkan modalnya ke perusahaan agar mendapatkan hasil dan dapat ikut serta dalam mengembangkan perusahaan, namun realita yang terjadi di pasar banyak perusahaan yang sudah tercatat di bursa efek masih menjalankan usahanya belum sesuai dengan prinsip syariah. Pasar modal syariah secara sederhana dapat diartikan sebagai pasar modal yang menerapkan prinsip syariah dalam kegiatan transaksi ekonomi dan terlepas dari hal-hal yang dilarang seperti riba, perjudian dan spekulasi.
\end{abstract}

Kata Kunci: Hukum trading dan saham syariah. 


\section{PENDAHULUAN}

Semakin berkembangnya perekonomian di dunia mengakibatkan perubahan yang signifikan di berbagai bidang kehidupan. Orang mulai melakukan transaksi ekonomi melalui berbagai cara, salah satunya adalah dengan menginvestasikan harta atau uangnya melalui pasar modal. Pasar modal dibentuk untuk mempermudah para investor mendapatkan asset dan mempermudah perusahaan menjual asset. Perusahaan dapat memperoleh dana segar dari para investor untuk melebarkan sayap usahanya. Indonesia sebagai Negara berkembang merupakan Negara yang membutuhkan banyak dana dalam melakukan peningkatan pembangunan baik fisik maupun bidang sumber daya manusia. Dalam hal itu maka kebutuhan akan dana melalui pasar modal merupakan keniscayaan. Apalagi didukung dengan minat masyarakat di Indonesia yang mulai meningkat dalam melakukan investasi di berbagai instrument pasar modal pada tahun 2018. Hal ini diikuti oleh para investor asing yang gencar dalam melakukan suntikan dana nya ke berbagai perusahaan di Indonesia. (Jogiyanto, 2000, 45)

Kegiatan jual beli saham dan obligasi di Indonesia sudah berlangsung sejak tahun 1880, dimana perdagangan saham dan obligasi dilakukan tanpa obligasi resmi. Secara keseluruhan terdapat berbagai metamorphosis perkembangan pasar modal pra kemerdekaan, antara lain dengan pendirian Amsterdam effectenbeurs, Nederlandsche Handel Maatschappi, Nederland Indische Escompto Bank (yang dinasionalisasi pada tahun 1957 menjadi Bank dagang Negara) serta Nederland Indische Handels Bank (Bank Bumi Daya). (Tumagor, 2008: 2-3).

Pada awal kemerdekaan, pasca perang dunia II, kegiaan pasar modal tidak banyak dilakukan, hal ini terjadi karena peraturan yang berlaku saat itu menjadikan para pemilik modal asing tidak berani menanamkan modalnya ke Indonesia. Disamping itu, diakui bahwa pada awal masa kemerdekaan tersebut, keadaan perekonomian Nasional dinilai tidak stabil. Hal ini menyebabkan pajak dan bea masuk belum dapat dipungut padahal pengeluaran Negara meningkat. Agar dapat membiayai perekonomian Negara, pemerintah melakukan sejumlah upaya untuk menambah pemasukkan Negara. Seperti dengan penghimpunan dana pinjaman Nasional, melalui UU No.4 Tahun 1946. Program ini didukung oleh masyarakat, sehingga Indonesia bangkit dari keterpurukan ekonomi pasca kemerdekaan. Walaupun surat utang pemerintah diperjualbelikan, namun sampai saat ini belum ditemukan catatan tentang nilai tukarnya. Hal ini dikarenakan pada saat itu belum didirikannya bursa. (Tandelilin, 2010: 27)

Meskipun dalam sejarahnya aktivitas pasar modal Indonesia sempat lumpuh, namun patut diakui bahwa fungsi pasar modal sangat esensial 
dalam perkembangan ekonomi Nasional. Hal inilah yang mendorong Menteri Keuangan Sumitro Djojohadikusumo membuka Bursa Efek di Jakarta pada tanggal 13 Juni 1952, yang mana transaksi baru di mulai tanggal 14 Juni 1952 dengan adanya transaksi 3\% Obligasi Republik Indonesia dan 4\% Obligasi Lening Gemeente Buitsenzogn 1937. (Tandelilin, 2010: 54)

Pasar modal di Indonesia tahun 2018 semakin mengalami trend peningkatan yang sangat signifikan. Fundamental ekonomi Indonesia memiliki tingkat pertumbuhan ekonomi yang positif dan konsisten. Meski ekonomi tidak tumbuh secara signifikan namun setiap tahun mengalami pertumbuhan di banding tahun-tahun sebelumnya. Selain itu pemerintah memiliki komitmen yang kuat untuk membayar kewajibannya terutama terkait hutang luar Negeri, sehingga tidak meninmbulkan presepsi pasar yang negative. Hal inilah yang menjadi daya tarik lainnya bagi investor. Naiknya peringkat utang Indonesia menjadi investment grade yang di kutip dari Reuters, S\&P dan Fit menempatkannya di peringkat PBB stabil dan positif. Hal ini menjadi sentiment positif bagi para investor global, artinya tingkat resiko investasi semakin menurun dan peluang investasi menjadi semakin menarik. (OJK : 2018)

Pasar modal dapat menjadi pilihan untuk mendapatkan penghasilan baik dalam jangka pendek maupun jangka panjang. Masyarakat dapat mendapatkan penghasilan tambahan dari investasinya, namun rata-rata mereka belum tahu akan hukum yang berkaitan dengan transaksi dan investasi di instrument pasar modal. Masyarakat seringkali menganggap bahwa jual beli saham merupakan transaksi yang haram karena ada unsur spekulasi dari fluktuasi harga. Meskipun ada para praktisi yang mengedukasi masyarakat tentang hukum perdagangan di pasar modal, namun masih banyak perdebatan yang terjadi. Padahal ada instrument dalam pasar modal yang sesuai dengan prinsip syariah dan masuk dalam kategori transaksi muamalah yang halal. (Umam, 2013: 77)

Dalam transaksi di pasar modal terdapat dua instrument yaitu pasar modal regular dan pasar modal syariah. Indonesia merupakan Negara yang mayoritas penduduknya beragama Islam. Hal itu harus di ikuti dengan literasi masyarakat berkaitan dengan bagaimana hukum transaksinya dan bagaimana kriteria perusahaan yang dikategorikan sebagai perusahaan syariah. Berkaitan dengan hal itu maka perlu di pilih mana transaksi di pasar modal yang dapat menjadi sumber yang halal dan tidak. Hal ini sudah menjadi respon yang positif di lantai bursa, pada bursa efek Indonesia telah ditetapkan dan dilakukan penyaringan mana efek yang sesuai syariah dengan memasukkannya kedalam daftar efek syariah (DES) sesuai dengan ketentuan Fatwa DSN MUI. (Martalena, 2011: 39) 


\section{KAJIAN LITERATUR}

Pasar modal syariah adalah pasar modal yang seluruh mekanisme kegiatannya terutama mengenai emiten, jenis efek yang diperdagangkan, dan mekanisme perdagangannya telah sesuai dengan prinsip syariah. Sedangkan yang dimaksud dengan efek syariah adalah efek sebagaimana dimaksud dalam peraturan perundang-undangan di bidang pasar modal yang akad, pengelolaan perusahaan, maupun cara penerbitannya memenuhi prinsip syariah. Adapun yang dimaksud dengan prinsip syariah adalah prinsip yang didasarkan oleh syariah ajaran Islam yang penetapannya dilakukan oleh DSN-MUI melalui fatwa. (Andri, 2014 : 112)

Sejarah pasar modal syariah di Indonesia dimulai dengan diterbitkannya Reksa Dana Syariah oleh PT. Danareksa Investment Management pada Juli 1997. Selanjutnya, Bursa Efek Indonesia (Bursa Efek Jakarta) bekerja sama dengan PT. Danareksa Investment Management meluncurkan Jakarta Islamic Index pada tanggal 3 Juli 2000 yang bertujuan untuk memandu investor yang ingin menginvestasikan dananya secara syariah. Pada tanggal 18 April 2001, untuk pertama kalinya Dewan Syariah Nasional Majelis Ulama Indonesia (DSN-MUI) mengeluarkan fatwa yang berkaitan langsung dengan pasar modal, yaitu Fatwa Nomor 20/DSNMUI/IV/2001 tentang pedoman pelaksanaan Investasi untuk Reksa Dana Syariah. Selanjutnya, instrument investasi syariah di pasar modal terus bertambah dengan kehadiran obligasi syariah PT Indosat Tbk pada awal September 2002. Instrument ini merupakan obligasi syariah pertama dan akad yang digunakan adalah akad mudharabah.

Sejarah pasar modal syariah juga dapat ditelusuri dari perkembangan institusional yang terlibat dalam pengaturan pasar modal syariah tersebut. Perkembangan tersebut dimulai dari MoU antara Bapepam dan DSN-MUI pada tanggal 14 Maret 2003. MoU menunjukkan adanya kesepahaman antara Bapepam dan DSN-MUI untuk mengembangkan pasar modal berbasis syariah di Indonesia.

Perbedaan secara umum antara pasar modal konvensional dengan pasar modal syariah dapat dilihat pada instrumen dan mekanisme transaksinya, sedangkan perbedaan nilai indeks saham syariah dengan nilai indeks saham konvensional terletak pada kriteria saham emiten yang harus memenuhi prinsip-prinsip dasar syariah. Secara umum, konsep pasar modal syariah dan pasar modal konvensional tidak jauh berbeda, meskipun dalam konsep pasar modal syariah disebutkan bahwa saham yang dniperdagangkan harus berasal dari perusahaan yang bergerak dalam sektor yang memenuhi kriteria syariah dan terbatas dari unsur ribawi, serta transaksi saham dilakukan dengan menghindarkan berbagai praktik spekulasi. (Khaerul Umam, 2013 : 38) 
Berkenaan dengan praktik pasar modal syariah di Indonesia, kronologis perkembangan pasar modal syariah yang terdiri atas perkembangan produk, dan peraturan terkait pasar modal syariah. Efekefek yang dapat diperdagangkan di pasar modal syariah telah diatur dalam peraturan Bapepam-LK Nomor IX.A.13 tentang Penerbit Efek Syariah. Dalam peraturan tersebut didefinisikan bahwa efek syariah adalah efek sebagaimana dimaksud dalam Undang-Undang Pasar Modal dan peraturan pelaksanaannya yang akad, cara, dan kegiatan usaha yang menjadi landasan penerbitannya tidak bertentangan dengan prinsipprinsip syariah di pasar modal. (Achsien, $2003: 122)$

Berikut ini adalah efek-efek yang diperdagangkan di pasar modal syariah Indonesia berdasarkan Peraturan Bapepam-LK Nomor IX.A.13:

1. Reksa dana syariah

2. Kontrak investasi kolektif efek beragun asset syariah

3. Efek beragun asset syariah

4. Sukuk, yang terbagi atas:

a. Asset berwujud tertentu ( $a^{\prime}$ yan maujudat)

b. Nilai manfaat atas asset berwujud (manaful a'yan)

c. Jasa (al khadamat)

d. Asset prosek tertentu (maujudat masyru' mu'ayyan), dan

e. Kegiatan investasi yang telah ditentukan (nasyath ististmarin khashah) (Umam, : 93)

Akad yang digunakan dalam penerbitan efek-efek tersebut antara lain: mudharabah, wakalah, musyarakah, salam, istishna, ijarah, dan kafalah. Adapun efek efek yang tidak boleh diperdagangkan di pasar modal syariah adalah efek-efek yang diterbitkan tidak sesuai dengan prinsip syariah di pasar modal, yang di dalamnya mengandung unsur dharar, gharar, riba', masyir, risywah, maksiat, dan kedzaliman.

\section{Hukum Trading Saham Syariah di Pasar Reguler}

Trading saham merupakan kegiatan transaksi jual beli saham berdasarkan ketentuan yang berlaku pada Bursa Efek Indonesia. Dalam jual beli atau trading saham perlu diketahui bahwa sertifikat kepemilikan saham adalah $\mathrm{T}+2$ setelah kesepakatan terjadinya transaksi. Ketetapan ini berlaku pada tanggal 26 November 2018 sebelumnya diberlakukan T+3 setelah transaksi. Namun, saham yang sudah di beli itu sudah bisa di transaksikan kepada anggota bursa lainnya.

Hukum perdagangan efek atau trading saham syariah pada dasarnya adalah mubah atau boleh namun berpedoman pada ketentuan khusus yang ditetapkan. Hal ini didasarkan pada Fatwa DSN MUI No.80 Tahun 2011 yang menyebutkan bahwa trading saham diperbolehkan yaitu dengan menggunakan akad jual beli (ba'i). Akad jual beli dinilai sah atas 
dasar kesepakatan pada harga serta jenis dan volume tertentu atas permintaan beli dan penawaran jual. Seorang pembeli atau trader boleh melakukan penjualan efek setelah akad jual beli, walaupun belum menyelesaikan administrasi transaksi pembeliannya (settlement) di kemudian hari berdasarkan prinsip qabdh hukmi. Selain itu persyaratan khusus yang lainnya adalah obyek yang diperjualbelikan adalah efek syariah yang bersifat ekuitas sesuai dengan prinsip syariah. Harga yang ditetapkan dalam transaksi tersebut harus berdasarkan pada harga pasar wajar melalui proses tawar menawar yang berkesinambungan ( $b a^{\prime} i$ al musawamah).

Mekanisme perdagangan efek juga mematuhi aturan yang ditetapkan oleh bursa efek. Bursa efek boleh menetapkan bahwa perdagangan efek dengan syarat hanya boleh dilakukan oleh anggota bursa efek, jadi penjual maupun pembeli yang akan melakukan transaksi harus menjadi anggota bursa efek. Akad penjual atau pembeli yang bukan anggota bursa efek dengan anggota bursa menggunakan akad jualah. Ketentuan lainnya ditetapkan berdasarkan syarat yang dikeluarkan oleh DSN MUI bahwa bursa efek harus menerapkan standar pengawasan dalam perdagangan di lantai bursa. Efek yang sudah masuk dalam indeks saham syariah selalu dipantau dan di evaluasi untuk di terbitkan pengumuman mana saja saham syariah yang baru masuk dan apa saja saham yang di delisting oleh indeks saham syariah. (Fatwa DSN MUI: 2012)

\section{Kegiatan Trading Saham yang tidak Sesuai dengan Syariah}

Pelaksanaan perdagangan efek yang terjadi selama ini walaupun para trader rata-rata sudah tahu akan indeks saham syariah dan akun syariah namun ada sebagian orang belum tahu akan bagaimana cara trading yang tidak melanggar syariah. Kegiatan trading itu harus dilakukan dengan prinsip kehati-hatian, serta tidak diperbolehkan melakukan spekulasi, manipulasi dan tindakan lain yang didalamnya mengandung unsur dharar, gharar, riba, maysir, riswah, maksiat dan kedzaliman, taghrir dan tindakan lainnya yang dilarang dalam al-qur'an dan hadist. Tindakan perdagangan pada pasar modal yang tidak sesuai dengan prinsip syariah meliputi:

Tindakan dalam kategori tadlis antara lain:

1. Front running merupakan tindakan anggota bursa efek yang melakukan transaksi lebih dahulu atas suatu efek tertentu, atas dasar informasi bahwa akan ada anggota yang melakukan transaksi dengan volume atas efek tersebut yang akan mempengaruhi harga pasar.

2. Misleading information merupakan pernyataan atau membuat keterangan palsu yang secara material tidak benar sehingga menyesatkan dan mempengaruhi harga efek di lantai bursa. (Fatwa DSN MUI: 2012) 
Tindakan dalam kategori Taghrir:

1. Wash sale (perdagangan semu yang tidak mengubah kepemilikan) transaksi antara penjual dan pembeli ini tidak menimbulkan perubahan kepemilikan/kemanfaatannya. (beneficiary of ownership) atas transaksi saham tersebut. Tujuannnya untuk membentuk harga naik, turun atau tetap sehingga menimbulkan kesan seolah-olah harga terbentuk melalui transaksi yang terkesan wajar.

2. Pre-arrange trade merupakan transaksi yang terjadi melalui pemasangan order beli dan jual pada rentang waktu yang hamper bersamaan yang terjadi karena adanya perjanjian pembeli dan penjual sebelumnya.

Tindakan dalam kategori Najsy

1. Pum and dump, kegiatan ini berupa aktivitas transaksi suatu efek yang diawali oleh pergerakan harga uptrend, yang disebabkan oleh inisiator beli yang membentuk harga naik sampai pada level tertinggi yang dengan tujuan untuk menciptakan kesempatan jual harga tinggi agar memperoleh keuntungan.

2. Hype and dump, aktivitas transaksi pada suatu efek yang diawali oleh pergerakan harga uptrend yang disertai dengan adanya informasi positif yang tidak benar, dilebih-lebihkan dan misleading dengan tujuan mendapatkan keuntungan yang maksimal.

3. Creating fake demand/supply (permintaan/penawaran palsu), adanya satu atau lebih pihak tertentu melakukan pemasangan order beli/jual pada level harga terbaik, tetapi jika harga yang dipasang itu sudah mencapai best price maka order tersebut di delete. Tujuannya untuk memberi pengaruh kepada pasar seoalah-olah terjadi permintaan/penawaran yang tinggi sehingga pasar terpengaruh untuk membeli atau menjual. (Fatwa DSN MUI: 2012)

Tindakan trading dalam kategori ikhtikar

1. Pooling interest, merupakan aktivitas transaksi atas suatu efek yang terkesan liquid, baik disertai dengan pergerakan harga maupun tidak, pada periode tertentu dan diramaikan oleh sekelompok anggota bursa efek tertentu. Tujuannnya untuk menciptakan kesempatan untuk menjual atau mengumpulkan saham atau menjadikan aktivitas saham tertentu menjadi benchmark.

2. Cornering, merupakan pola transaksi yang terjadi pada saham dengan kepemilikan public terbatas. Teradapat upaya dari pemegang saham mayoritas untuk menciptakan supply semu yang menyebabkan harga saham menurun pada pagi hari dan menyebabkan investor public melakukan short selling. Kemudian ada upaya pembelian yang dilakukan pemegang saham mayoritas hingga menyebabkan harga meningkat pada sesi sore sehingga pelaku short selling mengalami gagal serah karena membeli dengan harga yang lebih mahal. 
Tindakan yang termasuk dalam kategori Ghisysy antara lain

1. Marking at the close (pembentukan harga penutupan), yaitu penempatan order jual atau beli yang dilakukan di akhir hari perdagangan yang bertujuan menciptakan harga penutupan sesuai dengan yang diinginkan.

4. Alternate trade merupakan transaksi dari sekelompok anggota bursa tertentu dengan peran sebagai pembeli dan penjual secara bergantian serta dilakukan dengan volume yang terkesan wajar. Untuk memberi kesan suatu efek aktif diperdagangkan. (Fatwa DSN MUI: 2012)

Tindakan yang termasuk dalam kategori Ghabn Fahisy, antara lain:

Insider trading (perdagangan orang dalam), yaitu kegiatan illegal dilingkungan pasar finansial untuk mencari keuntungan yang dilakukan dengan cara memanfaatkan informasi internal, misalnya rencana-rencana atau keputusan-keputusan perusahaan yang belum dipublikasikan

Tindakan yang termasuk dalam kategori ba'I al ma'dum

Short selling ( $b a^{\prime} i$ al-maksyu/jual kosong) yaitu suatu cara yang digunakan dalam penjualan saham yang belum dimiliki dengan harga tinggi dengan harapan akan membeli kembali pada saat harga turun

Tindakan yang termasuk dalam kategori riba, antara lain: margin trading (transaksi dengan pembiayaan). Transaksi ini melakukan perdagangan efek dengan fasilitas pinjaman berbasis bunga (riba) atas kewajiban penyelesaian pembelian efek. (Fatwa DSN MUI: 2012)

\section{PEMBAHASAN}

Kegiatan pasar modal syariah di Indonesia secara umum tidak berbeda dengan kegiatan pasar modal yang telah dikenal selama ini. Pasar modal syariah di Indonesia dilaksanakan berdasarkan prinsip-prinsip syariah di pasar modal. Berdasarkan Bapepam-LK Nomor IX.A.13, prinsip-prinsip syariah di pasar modal adalah prinsip hukum Islam dalam kegiatan pasar modal yang berdasarkan fatwa Dewan Syariah Nasional Majelis Ulama Indonesia (DSN-MUI), sepanjang fatwa dimaksud tidak bertentangan dengan peraturan ini dan atau Peraturan Bapepam-LK yang didasarkan pada fatwa DSN-MUI.

Hukum mekanisme perdagangan saham menyangkut dua kriteria yaitu apa saham yang diperjualbelikan dan bagaimana trading saham yang sesuai dengan syariah. Saham syariah adalah efek yang diterbitkan pada perusahaan yang melakukan usahanya sesuai dengan prinsip syariah. Bursa Efek Indonesia sendiri sudah mengelompokkan saham-saham apa saja yang termasuk dalam saham syariah dengan di kategorikan pada Daftar Efek Syariah (DES). Setelah masuk daftar efek syariah kemudian di kelompokkan ke indeks saham yang terbaik dan yang umum. 
Dalam kategori saham yang regular dan syariah terdapat berbagai macam indeks yang sudah mengelompokkan saham apa saja yang tercatat sebagai saham syariah dan saham regular. Beberapa indeks saham syariah yang tercatat pada bursa efek Indonesia adalah: Indeks Saham Syariah Indonesia (ISSI) , Jakarta Islamic Index (JII), Jakarta Islamic Index 70 (JII70). Indeks Saham Syariah Indonesia (ISSI) yang diluncurkan pada tanggal 12 Mei 2011 adalah indeks komposit saham yang tercatat di BEI. Konstituen ISSI adalah seluruh saham syariah yang tercatat di BEI dan masuk kedalam Daftar Efek Syariah yang diterbitkan oleh OJK. Setiap hari sekali OJK merilis daftar efek yang masuk dalam kategori saham syariah. Terhitung sampai desember 2018 terdapat 399 daftar perusahaan yang terindex sebagai saham syariah. (IDX: 2018)

Jakarta Islamic Index (JII) merupakan indeks saham syariah yang pertama kali diluncurkan di pasar modal Indonesia pada tanggal 3 juli tahun 2000. Konstituen saham JII hanya terdiri 30 saham paling likuid yang terdaftar di BEI. Review saham JII dilakukan dalam jangka waktu dua kali dalam setahun yaitu pada bulan Mei dan Desember. BEI menentukan dan melakukan seleksi saham syariah yang menjadi konstituen di JII. Adapun kriteria likuiditas yang digunakan dalam menyeleksi 30 saham syariah yang menjadi konstituen JII adalah saham syariah yang sudah tercatat di ISSI selama 6 bulan terakhir, dipilih 60 saham berdasarkan rata-rata kapitalisasi pasar tertinggi selama 1 tahun terakhir. Dari 60 saham tersebut dipilih rata-rata nilai transaksi harian di pasar regular yang tertinggi.

Jakarta Islamic Index 70 (JII70) adalah indeks saham syariah yang diluncurkan oleh BEI pada tanggal 17 Mei 2018. Konstituen JII 70 terdiri 70 saham syariah paling likuid yang tercatat. Penyeleksiannya sama seperti JII hanya dengan kuota yang lebih banyak yaitu dipilih 150 saham syariah dengan kapitalisasi pasar tertinggi kemudian dipilih 70 saham yang mempunyai rata-rata nilai transaksi harian di pasar regular tertinggi. (IDX: 2018). (IDX: 2018)

\section{Trading saham di lantai bursa}

Seorang investor yang ingin menginvestasikan dananya pada saham di bursa efek harus membuat rekening dana nasabah. Rekening dana nasabah tersebut di buat dengan perantara perusahaan sekuritas. Banyak perusahaan sekuritas yang menyediakan berbagai fasilitas untuk mendukung kegiatan transaksi saham. Namun, hanya ada beberapa perusahaan sekuritas yang memfasilitasi transaksi trading secara syariah. Di Indonesia ada 115 perusahaan sekuritas yang terdaftar di bursa efek Indonesia. Diantara berbagai perusahaan sekuritas yang ada 10 perusahaan sekuritas terbaik berdasarkan survey dari pemeringkat sekuritas, yaitu: BNI Sekuritas, Henan Putihrai Sekuritas, Mirae Asset Sekuritas, Indo 
Premier Sekuritas, NH Korindo Sekuritas Indonesia, Mandiri Sekuritas, Samuel Sekuritas Indonesia, MNC Sekuritas, RHB Sekuritas Indonesia, Valbury Sekuritas Indonesia. Walupun perusahaan sekuritas tersebut menduduki 10 peringkat tertinggi, namun beberapa perusahaan itu juga belum menyediakan shariah online trading system. (Saham Syariah: 2018)

Shariah online trading system (SOTS) merupakan sarana yang disediakan oleh perusahaan sekuritas sebagai system yang menyelenggarakan transaksi saham berdasarkan prinsip syariah. Saham yang akan dibeli oleh seorang trader dengan perusahaan yang tidak masuk dalam kategori Daftar Efek Syariah maka otomatis dalam system tersebut tidak dapat melakukan pembelian. Dalam system itu terdapat peringatan bahwa saham yang dibeli bergerak dalam bidang haram, terdapat unsur yang mengandung riba, ataupun unsur lain yang tidak diperbolehka dengan screening yang ketat. Jadi saham yang dapat dibeli oleh seorang trader dengan menggunakan SOTS sudah di screening secara ketat.

Sekuritas yang telah mengaplikasikan SOTS dan sudah tersertifikasi oleh Dewan Syariah Nasional MUI terdapat 12 perusahaan sekuritas yaitu:

\section{Tabel 1}

Daftar Sekuritas SOTS

\begin{tabular}{lllll}
\hline No & Perusahaan & Nama Produk & $\begin{array}{l}\text { Tahun } \\
\text { Sertifikasi }\end{array}$ & Masa Berlaku \\
\hline 1 & $\begin{array}{l}\text { PT Indo Premier } \\
\text { Securitas }\end{array}$ & IPOT syariah & 2011 & $14 / 11 / 17$ \\
\hline 2 & PT Daiwo Securities & HOTS syariah & 2012 & $11 / 03 / 17$ \\
\hline 3 & $\begin{array}{l}\text { PT Sucorinvest Central } \\
\text { gani }\end{array}$ & SPOT syariah & 2014 & $24 / 03 / 17$ \\
\hline 4 & PT First Asia Capital & FAST syariah & 2015 & $25 / 11 / 18$ \\
\hline 5 & PT MNC Sekurities & MNC trade & 2016 & $11 / 05 / 19$ \\
& & syariah & & \\
\hline 6 & PT Panin Sekurites & POST syariah & 2016 & $26 / 05 / 19$ \\
\hline 7 & PT BNI Sekurities & eSmart & 2012 & $01 / 06 / 19$ \\
& & syariah & & $20 / 06 / 19$ \\
\hline 8 & PT Henan Putihrai & HPX syariah & 2016 & $13 / 10 / 19$ \\
\hline 9 & PT Mandiri Sekurities & MOST syariah & 2012 & $13 / 10 / 19$ \\
\hline 10 & PT Philip Sekurities & $\begin{array}{l}\text { POEMS } \\
\text { Syariah }\end{array}$ & 2016 & Proses \\
\hline 11 & PT Trimegah Securities & $\begin{array}{l}\text { iTrimegah } \\
\text { syariah }\end{array}$ & 2012 & Perpanjangan \\
\hline 12 & PT Phintraco Securities & $\begin{array}{l}\text { Profits } \\
\text { Syariah }\end{array}$ & 2013 & Proses \\
& & Perpanjangan
\end{tabular}

Sumber: syariahsaham.com 
Dari data perusahaan sekuritas yang menyediakan fasilitas syariah online trading tersebut sudah tersertifikasi MUI, namun fenomena yang terjadi di masyarakat terkadang tidak memilih system tersebut. Hal ini dikarenakan beberapa masyarakat ingin memiliki saham di perusahaan tapi tidak dapat dibeli oleh system karena tidak terindeks syariah. (M. Irsan Nasarudin, 2011: 37)

Pada SOTS tersebut hanya saham syariah yang dapat di transaksikan, transaksi beli saham syariah hanya dapat dilakukan secara tunai tidak boleh adanya margin trading, tidak dapat melakukan transaksi jual saham syariah yang belum dimiliki (short selling). Laporan kepemilikan saham syariah tersebut juga di pisah dengan kepemilikan uang, sehingga saham syariah yang dimiliki tidak dihitung sebagai modal. SOTS itu memudahkan para trader dalam melaksanakan berbagai transaksi jual beli saham, karena trader tidak perlu menscreening saham dari perusahaan apa mengandung unsur yang halal ataukah tidak. System ini mengefisiensi waktu seorang trader dalam bertransaksi sesuai dengan prinsip syariah. (Burhanuddin, 2009: 77)

Berdasarkan penuturan dari Kepala Divisi Pasar Modal Syariah BEI Irwan Abdalloh mengungkapkan, sepanjang 2018 jumlah investor Tanah Air tumbuh sebanyak $92 \%$ menjadi 44.536 investor dari capaian tahun sebelumnya yang hanya 23.207 investor. Dari jumlah tersebut sekitar 56\% merupakan investor syariah aktif. Hal ini dapat disimpulkan bahwa berbagai perdebatan dari masyarakat tentang saham yang dianggap mereka adalah haram, namun ada solusi dari hal itu yakni ada transaksi saham yang sesuai syariah dan halal. Hal ini dapat dibuktikan dari data tersebut ternyata banyak investor yang mengikuti trading saham yang sesuai syariah. Jumlah investor syariah dibandingkan dengan total jumlah investor Tanah Air baru 5,2\%. Namun, angka tersebut sudah tembus target bursa di 2020 yakni 5\%. Di sisi lain, irwan abdalloh juga mengklaim bahwa transaksi saham syariah mendominasi pergerakan pasar Saham Tanah Air. Di mana, sejak 2011 jumlah saham syariah sukses tumbuh $170 \%$. Sedangkan sepanjang 2018 kinerja Indeks Saham Syariah Indonesia (ISSI) berkontribusi $65 \%$, diikuti kontribusi market cap 52\%, volume transaksi 53\%, value $46 \%$ dan frekuensi 65\% dibandingkan kinerja IDX. Sejak diluncurkan pada tahun 2011 hingga Januari 2019, return saham ISSI telah tumbuh 54\% dan menjadi yang kedua tertinggi dibandingkan indeks saham syariah dunia setelah Dow Jones Islamic Market World. (IDX :2018)

Dalam hal presepsi masyarakat saat ini tentang literasi pasar modal terutama pasar modal syariah masih cukup rendah yakni 1,25\% dengan inklusi sebesar $0,11 \%$, namun hal itu sudah melebihi target yang ditetapkan oleh BEI. Seminar dan workshop pasar modal syariah gencar dilakasanakan diberbagai kota di Indonesia. Hampir setiap bulan BEI melalui divisi pasar 
modal syariahnya memberikan edukasi kepada masyarakat. Masyarakat menjadi sangat antusias terhadap pasar modal. Mereka senantiasa mengikuti informasi yang disediakan oleh BEI dan Perusahaan sekuritas. Dengan berbagai keuntungan yang ada seperti mendapatkan dividen dan capital gain yang wajar dari perusahaan itu menjadi hal yang menarik untuk trading saham. Keuntungan lainnya adalah dengan jumlah dana yang murah mereka dapat membeli saham dan membuka rekening dana nasabah. PT Indo Premier misalnya menyediakan fasilitas saldo minimal sebesar Rp. 100.000,- sudah dapat membuka rekening dana nasabah. Dana itu sudah dapat dibelikan untuk beberapa lot saham.

Dari berbagai keuntungan yang ada juga terdapat lembaga penunjang yang medukung pasar modal. Ada 27 Penjamin emisi, 14 Bank Kustodian, 10 pihak penerbit daftar efek syariah, 49 manajer investasi, 12 sistem online trading syariah, 66 ahli syariah pasar modal, 2 Bank syariah sebagai administrator rekening dana investor. (OJK: 2018) Lembaga dan beberapa pihak tersebut berfungsi melancarkan kegiatan transaksi di pasar modal dan mengamankan dana dari para investor sehingga stabilitas ekonomi Negara terjaga dan tingkat pertumbuhan ekonomi dengan adanya perusahaan yang berkembang karena adanya pasar modal syariah juga semakin meningkat.

\section{KESIMPULAN}

Berdasarkan keadaan yang berlangsung di lantai bursa dan sesuai dengan fatwa DSN MUI No.80 Tahun 2011 tentang prinsip syariah di Pasar Modal maka hukum Investasi dan transaksi di Pasar modal pada dasarnya adalah mubah atau boleh. Namun, harus dilaksanakan berdasarkan ketentuan khusus yang telah ditetapkan. Pertama transaksinya berupa investasi berdasarkan akad kerjasama antara dua belah pihak. Apabila terjadi jual beli/trading saham antara anggota bursa maka transaksinya harus sesuai dengan akad yang berlaku yaitu ba'I (jual beli regular) dam ba'i al musawamah (jual beli berkesinambungan). Transaksi yang tidak diperbolehkan adalah ketika saham yang dibeli tidak masuk dalam daftar efek syariah atau indeks saham syariah. Selanjutnya adalah pelaksanaan transaksi jual beli nya tidak mengandung unsur-unsur yang tidak sesuai dengan syariah seperti dharar, gharar, maysir, riba dan hal lain yang diatur dalam al-Qur'an, hadist, ijma', Qiyas dan Fatwa DSN MUI.

Disamping Fawa DSN MUI, berbagai aturan lainnya juga tersedia untuk mengatur hukum transaksi pada pasar modal syariah. Peraturan otoritas jasa keuangan (POJK) No. 15 s.d No. 19 Tahun 2015 tentang penerapan prinsip syariah di pasar modal, ahli syariah, penerbitan dan persyaratan efek syariah berupa saham, penerbitan dan persyaratan sukuk, penerbitan dan persyaratan reksa dana syariah. 
Dari berbagai data yang disebutkan tersebut, dapat diketahui bahwa perdebatan tentang hukum saham syariah sebenarnya sudah terjawab dengan berbagai landasan hukum yang dikeluarkan oleh DSN MUI, Peraturan Otoritas Jasa Keuangan (POJK) dan Peraturan Bursa Efek Indonesia (BEI). Aturan-aturan tersebut dipaparkan secara komprehensif dan sistematis dalam mengatur segala transaksi yang sesuai dengan prinsip syariah. Masyarakat harusnya sadar bahwa transaksi trading di bursa hukumnya adalah mubah apabila sesuai dengan prinsip syariah dan tidak melaksanakan transaksi yang dilarang oleh DSN MUI. Edukasi yang merata kepada masyarakat perlu dilakukan guna memberikan pemahaman bahwa trading saham syariah yang melalui SOTS adalah mubah.

\section{DAFTAR PUSTAKA}

Achsien, Iggi H, (2003), investasi syariah di pasar modal; menggagas konsep dan praktek, Jakarta: PT Gramedia Pustaka

Ali Arifin, (2007), Membaca saham, Yogyakarta; Andi Offset

Burhanuddin Susanto, (2009), Pasar Modal Syariah (tinjauan hukum), Yogyakarta; UII Press

Eduardus Tandellin,(2010), Portofolio dan Investasi Teori dan Aplikasi, Kanisius, Yogyakarta: Kanisius

Iggi H. Akhsin, Investasi Syariah di Pasar Modal Menggagas Konsep dan Praktek Manajemen Portofolio Syariah, Gramedia Pustaka Utama, Jakarta, 2005

Jogiyanto (2000), Teori Portofolio dan Analisis Investasi, Yogyakarta: BPFE

Kharis fadlullah hana, (2018), Faktor-Faktor Yang Mempengaruhi Keputusan Non Muslim Menjadi Anggota Pada KSPPS Fastabiq Khoiru Ummah Pati, Malia: Journal Islamic Banking and Finance Vol.2 No.2

M.S. Tumanggor (2008). Pengenalan Pasar Modal : Investasi dan Penanaman Modal, Jakarta: F Media.

M. Irsan Nasarudin, dkk, (2011), Aspek Hukum Pasar Modal Indonesia. Jakarta: Prenada Media Group.

Martalena (2011), Pengantar pasar modal, edisi pertama, Yogyakarta: Andi offset

Khaerul Umam (2013), Pasar Modal Syariah, Bandung; Pustaka Setia

www.idx.com

wWw.ojk.com

wWw.sahamsyariah.com

www.dsnmui.or.id 